Oluwasola Emmanuel Ojo ${ }^{1}$

DOI: 10.31902/LL.2019.6.1.2

\title{
METADISCOURSE MARKERS IN NEWSPAPER COLUMNS: A STUDY OF TEXTS WRITTEN BY NIGERIAN COLUMNISTS
}

\begin{abstract}
A number of taxonomies have been proposed for metadiscourse analysis of texts, and within most of these taxonomies, metadiscourse markers have been organised under the functional headings of textual and interpersonal metadiscourse. However, there is the need to know if writers inadvertently place more emphasis on organising discourse or building writer-reader relationship. The aim of this study is to examine the use of textual and interpersonal metadiscourse categories and sub-categories by Nigerian columnists in their construction of arguments and attainment of persuasion. Ten columns were selected from five Nigerian newspapers and Dafouz-Milne's (2008) classification of metadiscourse categories was employed for the analysis. Findings reveal that Nigerian columnists employed both the textual and interpersonal metadiscourse markers, except reminders and announcements, in their texts. Also, it is established that interpersonal metadiscourse markers were more profusely used than the textual metadiscourse markers. This shows that, while there is a great discernible focus on discourse organisation, Nigerian columnists place more emphasis on establishing and maintaining rapport with their readers.
\end{abstract}

Key Words: textual metadiscourse, interpersonal metadiscourse, newspaper discourse, Nigerian columnists, persuasion

\section{Introduction}

Most newspapers have dedicated pages known as opinion sections. Within these, one can find columns, political cartoons, letters to the editor, editorials, etc. (Bednarek and Caple, 2012). These texts focus on topics that are considered by the entire populace "to be of particular societal importance at the time of publication" (Le, 2004: 688). A column is a subgenre of persuasive text that has the sole purpose of persuading and convincing the readers to follow and agree with the writer's stance (van Dijk, 1988). A column can further be grouped into two: regular column and letter to the editor. Regular columns are written by columnists who are considered to be experts. These experts have dedicated pages where they express their viewpoints that are usually not the official viewpoints of the newspaper. Also, a columnist has a particular day of the week for his or her column to be published. As a result of this, it is common in Nigeria for one to see readers buying a particular newspaper on a particular day just because of their favourite

\footnotetext{
${ }^{1}$ Doctoral student at the Faculty of Arts, University of Ilorin, Nigeria.
} 
columnist. Other features of regular columns are dedicated column name, name of the columnist (excluding professional title), e-mail address and mobile phone number. However for mobile phone number, it is common to see "SMS only". This means the columnists can only be reached through the Short Message Service. The reason for this is probably to prevent them from being inundated with calls from readers, whether to criticise or commend them. On the other hand, letter to the editor is written by individuals to share their views on issues of national importance. While some newspapers tag the page as 'letter to the editor', others do not and just put it in the opinion pages. Only the name and location of writer are stated. For example, "Mr. XX writes from Ilorin". The major difference between letter to the editor and regular column is that any writer can feature in the former while the reader knows the writer to feature on a particular day in the latter.

Columnists need to organise their ideas and arguments in such a way that the readers will be easily convinced to reason along with them. More importantly, a columnist needs to interact well with the readers and build a writer-reader relationship and emotional ties with them for persuasive goals to be attained (Sukma and Sujatna, 2014). Metadiscourse markers have been seen as linguistic tools that writers of persuasive texts employ to achieve the purposes of interacting and building relationship with their readers (Hyland and Tse, 2004; Dafouz Milne, 2008). As a linguistic field of enquiry, metadiscourse is used to investigate how texts are organised and produced in order to persuade and guide the readers through the texts. Hyland and Tse (2004: 156) posit that metadiscourse "seems to offer a motivated way of collecting under one heading, the range of devices writers use to explicitly organise their texts, engage readers, and signal their attitudes to both their materials and their audience". In other words, metadiscourse is the general term that contains "cohesive and interpersonal features" that help the readers of a text to "connect, organise, and interpret material in a way preferred by the writer and with regard to the understandings and values of a particular discourse community" (Hyland and Tse, 2004: 157).

Some of the linguistic devices that serve as metadiscourse markers can also be found in other linguistic fields of enquiry. For example, Ojo (2013) explored the uses of hedges, conjunctions and exemplifiers in the inauguration speeches of President Barak Obama of United States of America and President Goodluck Jonathan of Nigeria. Also, hedges and certainty markers (boosters) have been researched extensively as modality in pragmatic studies. However, it has been posited that little is known about hedging concerning its use, frequency and distribution in different genres and disciplines (Hyland, 1998; 
Farrokhi and Emami, 2008). This has led credence to the need to explore metadiscourse in different genres. However, within these genres, there is the need to know if writers use metadiscourse markers to focus more on organising discourse or building writer-reader relationship. Therefore, the aim of this study is to explore the use, frequency of occurrence and distribution of metadiscourse markers in opinion texts written by Nigerian columnists. The columnists are Niyi Akinnaso from The Punch, Oyinkan Medubi from The Nation, Luke Onyekakeyah from The Guardian, Yusuf Muhammed from Daily Trust and Funke Egbemode from Sunday Sun.

\section{Literature Review}

The concept of metadiscourse has developed significantly since when Zelling Harris first coined it in 1959 (Sukma and Sujatna, 2014). Many researchers have come up with different taxonomies of metadiscourse: Vande Kopple (1985), Crismore et al. (1993), Hyland (1998), Hyland and Tse (2004), Hyland (2005) and Dafouz-Milne (2008). Amiryousefi and Rasekh (2010: 161) argue that virtually all the taxonomies have followed Halliday's (1994) "tripartite conception of metafunctions which distinguishes between the ideational elements of a text, the ways we encode our experiences of the world and its textual and interpersonal functions". However, Hyland and Tse (2004) report that the concept of metadiscourse does not influence Halliday's thinking while metadiscourse researchers have not really subscribed to a functional grammar and Halliday's argument of the three metafunctions functioning simultaneously. Based on different taxonomies, researchers have been employing metadiscourse as a tool to investigate genre-based texts.

\section{Vande Kopple's (1985) Metadiscourse Taxonomy}

This categorisation is the first serious work on the organisation of metadiscourse markers. It consists of text connectives, code glosses, validity markers, narrators, illocution markers, attitude markers and commentaries, as seven metadiscourse markers that are grouped under textual and interpersonal categories. As cited in Hyland and Tse (2004: 162), Vande Kopple posited that textual metadiscourse "shows how we link and relate individual propositions so that they form a cohesive and coherent text and how individual elements of those propositions make sense in conjunction with other elements of the text". On the other hand, interpersonal metadiscourse "can help us express our personalities and our reactions to the propositional content of our texts and characterise the interaction we would like to have with our readers about that content". The categorisation, despite being the first systematic 
organisation of metadiscourse, has been criticised for being vague and functionally overlapping. According to Hyland (2005: 32), "one obvious problem is the difficulty of distinguishing narrators and attributors, particularly in academic writing where citation is used to perform a variety of rhetorical functions". Hyland is of the opinion that the functions are not performed in isolation. It is possible for a writer to select a citation in order to achieve several purposes at the same time. Therefore, "it is not entirely clear how far either the analyst or the reader can determine which function may be intended".

Within the textual category, there are text connectives, code glosses, validity markers and narrators. Under the interpersonal category, there are illocution markers, attitude markers and commentaries. This is shown in the table below:

\begin{tabular}{|c|c|}
\hline $\begin{array}{c}\text { Category } \\
\text { Textual } \\
\text { metadiscourse }\end{array}$ & Function \\
\hline Text connectives & $\begin{array}{l}\text { Used to help show how parts of a text are connected to one } \\
\text { another. Include sequencers (first, next, in the second } \\
\text { place), reminders (as I mentioned in chapter } 2 \text { ), and } \\
\text { topicalisers, which focus attention on the topic of a text } \\
\text { segment (with regard to, in connection with). }\end{array}$ \\
\hline Code glosses & $\begin{array}{l}\text { Used to help readers to grasp the writer's intended } \\
\text { meaning: based on the writer's assessment of the reader's } \\
\text { knowledge, these devices reward, explain, define, or clarify } \\
\text { the sense of a usage. }\end{array}$ \\
\hline Validity markers & $\begin{array}{l}\text { Used to express the writer's commitment to the } \\
\text { probability of or truth of a statement. These include } \\
\text { hedges (perhaps, might, may), emphatics (clearly, } \\
\text { undoubtedly), and attributers which enhance a position by } \\
\text { claiming the support of a credible other (according to } \\
\text { Einstein) }\end{array}$ \\
\hline Narrators & $\begin{array}{l}\text { Used to inform readers of the sources of the information } \\
\text { presented-who said or wrote something (according to } \\
\text { Smith, the Prime Minister announced that). }\end{array}$ \\
\hline $\begin{array}{l}\text { Interpersonal } \\
\text { metadiscourse }\end{array}$ & ( \\
\hline Illocution markers & $\begin{array}{l}\text { Used to make explicit the discourse acts the writer is } \\
\text { performing at certain points (to conclude, I hypothesise, to } \\
\text { sum up, we predict). }\end{array}$ \\
\hline Attitude markers & $\begin{array}{l}\text { Used to express the writer's attitude to the propositional } \\
\text { material he or she presents (unfortunately, interestingly, I } \\
\text { wish that, how awful that). }\end{array}$ \\
\hline Commentaries & $\begin{array}{l}\text { Used to address readers directly, drawing them into an } \\
\text { implicit dialogue by commenting on the reader's probable } \\
\text { mood or possible reaction to the text (you will certainly } \\
\text { agree that, you might want to read the third chapter first). }\end{array}$ \\
\hline
\end{tabular}

Table 1: Vande Kopple's Classification System for Metadiscourse 
It should be noted that attempts have been made by subsequent researchers to refine this classification. Vande Kopple (1997) himself refined his taxonomy by relabeling validity markers as epistemological markers which also subsume evidentials and modality. Thus, irrespective of the criticism, Vande Kopple's classification should be acknowledged for developing a model for other researchers to follow.

\section{Crismore et al.'s (1993) Metadiscourse Taxonomy}

Crismore et al. analysed the US and Finnish students' use of metadiscourse in forty persuasive essays. They kept the two main categories of textual and interpersonal functions introduced by Vande Kopple (1985). However, they separated and reorganised the subcategories. As shown in the table below, the textual metadiscourse was divided into two categories of textual and interpretive markers:

\begin{tabular}{|c|c|c|}
\hline $\begin{array}{l}\text { Category: textual } \\
\text { metadiscourse }\end{array}$ & Function & Examples \\
\hline Textual markers & & \\
\hline Logical connectives & $\begin{array}{l}\text { Show connection between } \\
\text { ideas }\end{array}$ & Therefore; so; in addition; and \\
\hline Sequencers & $\begin{array}{l}\text { Indicate sequence/ordering } \\
\text { of material }\end{array}$ & First; next; finally; 1, 2, 3 \\
\hline Reminders & $\begin{array}{l}\text { Refer to earlier text } \\
\text { material }\end{array}$ & As we saw in chapter one \\
\hline Topicalisers & Indicate a shift in topic & Well, now we discuss... \\
\hline Interpretive markers & & \\
\hline Code glosses & Explain text material & For example; that is \\
\hline Illocution markers & Name the act performed & To conclude; in sum; I predict \\
\hline Announcements & $\begin{array}{l}\text { Announce upcoming } \\
\text { material }\end{array}$ & In the next section \\
\hline \multicolumn{3}{|l|}{$\begin{array}{l}\text { Interpersonal } \\
\text { metadiscourse }\end{array}$} \\
\hline Hedges & $\begin{array}{l}\text { Show uncertainty to the } \\
\text { truth of assertion }\end{array}$ & Might; possible; likely \\
\hline Certainty markers & $\begin{array}{l}\text { Express full commitment to } \\
\text { assertion }\end{array}$ & Certainly; know; shows \\
\hline Attributers & $\begin{array}{l}\text { Give source/support of } \\
\text { information }\end{array}$ & Smith claims that... \\
\hline Attitude markers & $\begin{array}{l}\text { Display writer's affective } \\
\text { values }\end{array}$ & I hope/agree; surprisingly \\
\hline Commentary & $\begin{array}{l}\text { Build relationship with } \\
\text { reader }\end{array}$ & You may not agree that \\
\hline
\end{tabular}

Table 2. Metadiscourse Categorisation by Crismore et al.

This division of textual metadiscourse into two subcategories in the classification has been criticised for not having sufficient justification (Hyland, 2005; Latawiec, 2012). The categorisation also considered the 
intertextual function of illocution markers rather than having an interpersonal function, as presented in Vande Kopple's taxonomy. Despite the attempt to improve on Vande Kopple's taxonomy, some apparent abnormalities still persist. It is not clear why Crismore et al. put reminders under textual markers and announcements under interpretive markers, which is a different subcategory. Another problem is Crismore et al.'s assertion that subordinators are meant for grammaticality and not for metadiscoursal function. Coordinating conjunctions and conjunctive adverbs are seen as metadiscourse but not subordinating conjunctions. They argue that the omission of the coordinating conjunction and or the conjunctive adverb therefore does not mean one cannot have a well-formed independent clause (Hyland, 2005). Thus, metadiscourse items are seen as "the product of choice rather than syntactic necessity" (p. 34). However, it should be noted that the foundation of metadiscourse is that writers can be innovative in their writings as they are being conscious of the choices they make in their writings. Therefore, grammatical choices can also function as metadiscourse and "create well-formed sentences" (Hyland 2005: 34).

Subsequently, other metadiscourse taxonomies such as Hyland's (2005) and Dafouz-Milne's (2008) were developed. Of these taxonomies, only Dafouz-Milne's taxonomy was developed purposely to analyse opinion columns. Therefore, Dafouz-Milne's classification of metadiscourse is employed as the framework of this study. For example, Crismore et al.'s (1993) classification was employed by Marandi (2003) to analyse Persian and English Master's theses while Hyland and Tse's (2004) taxonomy was used by Zarei and Mansoori (2007) to analyse English and Persian research articles. However, Dafouz-Milne came up with her taxonomy in her analysis of British and Spanish opinion columns. Hence, it can be said that the taxonomy is suitable for this study. Also, the introduction of subcategories in this classification makes it distinct from other taxonomies. These subcategories help in the simplification and in the explanation of the macro-categories.

\section{Theoretical Framework}

Dafouz-Milne (2008) used the framework of metadiscourse taxonomies introduced by Vande Kopple (1985) and Crismore et al. (1993), where metadiscourse resources are organised under the functional headings of textual and interpersonal metadiscourse. She also aligned her study with Hyland's (2005) principle that metadiscourse categories are all interpersonal. As shown in the tables below, she however continued with the duality of textual and interpersonal functions found in previous studies: 


\begin{tabular}{|c|c|c|}
\hline Macro-category & Subcategory & Examples \\
\hline \multicolumn{3}{|l|}{ Logical Markers } \\
\hline Express semantic relationships & Additive & and; furthermore; in \\
\hline between discourse stretches & Adversative & $\begin{array}{l}\text { addition; moreover... } \\
\text { or; however; but... }\end{array}$ \\
\hline & Consecutive & so (as a result); therefore; \\
\hline & & as a consequence... \\
\hline & Conclusive & finally; in any case... \\
\hline \multicolumn{3}{|l|}{ Sequencers } \\
\hline $\begin{array}{l}\text { Mark particular positions in a } \\
\text { series }\end{array}$ & & $\begin{array}{l}\text { First; second; on the one } \\
\text { hand; on the other... }\end{array}$ \\
\hline \multicolumn{3}{|l|}{ Reminders } \\
\hline $\begin{array}{l}\text { Refer back to previous sections in } \\
\text { the text }\end{array}$ & & $\begin{array}{l}\text { Let us return to; as was } \\
\text { mentioned before... }\end{array}$ \\
\hline \multicolumn{3}{|l|}{ Topicalisers } \\
\hline Indicate topic shifts & & $\begin{array}{l}\text { In political terms; in the case } \\
\text { of the NHS... }\end{array}$ \\
\hline \multicolumn{3}{|l|}{ Code glosses } \\
\hline \multirow[t]{3}{*}{$\begin{array}{l}\text { Explain, rephrase or exemplify } \\
\text { textual material }\end{array}$} & & $\begin{array}{l}\text { When (as with the Tories } \\
\text { now)... }\end{array}$ \\
\hline & $\begin{array}{l}\text { Punctuation } \\
\text { devices } \\
\text { Reformulators }\end{array}$ & $\begin{array}{l}\text { Tax evasion: it is deplored in } \\
\text { others but not in oneself. } \\
\text { In other words; that is; to put } \\
\text { it simply... }\end{array}$ \\
\hline & Exemplifiers & For example; for instance... \\
\hline Illocutionary markers & & \\
\hline $\begin{array}{l}\text { Explicitly name the act the writer } \\
\text { performs }\end{array}$ & & $\begin{array}{l}\text { I propose; I hope to } \\
\text { persuade... }\end{array}$ \\
\hline Announcements & & \\
\hline $\begin{array}{l}\text { Refer forwards to future sections } \\
\text { in the text }\end{array}$ & & $\begin{array}{l}\text { There are many good reasons; } \\
\text { as we'll see later... }\end{array}$ \\
\hline
\end{tabular}

Table 3: Dafouz-Milne's Textual Metadiscourse markers 


\begin{tabular}{|c|c|c|}
\hline Macro-category & Subcategory & Examples \\
\hline $\begin{array}{l}\text { Hedges } \\
\text { Express partial } \\
\text { commitment to } \\
\text { the truth-value of } \\
\text { the text }\end{array}$ & $\begin{array}{l}\text { Epistemic verbs } \\
\text { Probability adverbs } \\
\text { epistemic expressions }\end{array}$ & $\begin{array}{l}\text { May; might; it must be two } \\
\text { o'clock } \\
\text { probably; perhaps; maybe } \\
\text { It is likely }\end{array}$ \\
\hline $\begin{array}{l}\text { Certainty } \\
\text { markers } \\
\text { Express total } \\
\text { commitment to } \\
\text { the truth-value of } \\
\text { the text }\end{array}$ & & $\begin{array}{l}\text { Undoubtedly; clearly; } \\
\text { certainly }\end{array}$ \\
\hline $\begin{array}{l}\text { Attributors } \\
\text { Refer to the } \\
\text { source of } \\
\text { information }\end{array}$ & & $\begin{array}{l}\text { ' } x \text { ' claims that...; As the Prime } \\
\text { Minister remarked }\end{array}$ \\
\hline $\begin{array}{l}\text { Attitude } \\
\text { markers } \\
\text { Express writer's } \\
\text { affective values } \\
\text { towards text and } \\
\text { readers }\end{array}$ & $\begin{array}{l}\text { Deontic verbs } \\
\text { Attitudinal adverbs } \\
\text { Attitudinal adjectives } \\
\text { Cognitive verbs }\end{array}$ & $\begin{array}{l}\text { Have to; we must understand; } \\
\text { needs to Unfortunately; } \\
\text { remarkably; pathetically } \\
\text { It is absurd; it is surprising } \\
\text { I feel; I think; I believe }\end{array}$ \\
\hline $\begin{array}{l}\text { Commentaries } \\
\text { Help to establish } \\
\text { reader- writer } \\
\text { rapport through } \\
\text { text }\end{array}$ & $\begin{array}{l}\text { Rhetorical questions } \\
\text { Direct address to } \\
\text { reader } \\
\text { Inclusive expressions } \\
\text { Personalisations } \\
\text { Asides }\end{array}$ & $\begin{array}{l}\text { What is the future of Europe, } \\
\text { integration or disintegration? } \\
\text { You must understand, dear } \\
\text { reader } \\
\text { We all believe; let us } \\
\text { summarise } \\
\text { What the polls are telling me } \\
\text { I do not want } \\
\text { Diana (ironically for a } \\
\text { Spencer) was not of the } \\
\text { establishment }\end{array}$ \\
\hline
\end{tabular}

Table 4. Dafouz-Milne's Interpersonal Metadiscourse Markers

Textual metadiscourse has seven major categories: logical markers, sequencers, reminders, topicalisers, code glosses, illocutionary markers and announcements. Two of them, logical markers and code glosses then have subcategories. On the other hand, interpersonal metadiscourse is classified into five major categories of hedges, certainty markers, attributors, attitude markers and commentaries. Three of them, hedges, attitude markers and commentaries are further divided 
into subcategories. It is the introduction of these subcategories that differentiates this taxonomy from that of Crismore et.al (1993).

Dafouz-Milne employed her metadiscourse model to contrast texts written by British and Spanish columnists. She explored the metadiscourse markers employed in 40 opinion columns from English and Spanish newspapers. 20 opinion columns were taken each from The Times (British) and El Pais (Spanish). The aim of the study was to identify the metadiscourse markers that are used in newspaper discourse (opinion columns), as well as finding the markers that are used more for persuasive purposes.

Dafouz-Milne's findings reveal that metadiscourse markers are crucial in the construction of persuasion in opinion columns and that there are cross-cultural variations in the employment of metadiscourse. Spanish writers prefer additive markers while English writers prefer adversative ones. She is of the opinion that the reason for that is the fact that in Spanish, argumentation is usually contracted through the addition of "positive warrants to the thesis statement, always moving in the same direction" (Dafouz-Milne 2008:105). On the other hand, the English arguments are considered to follow a "dialectical approach" that looks at the pros and cons of an argument, thus, the use of adversative markers.

The study concludes that there are similarities and differences in the use of metadiscourse markers in Spanish and English opinion columns. It claims that the similarities can be attributed to the fact that opinion columns (newspaper-genre) have their characteristics and conventions across languages that are beyond national culture. On the other hand, Dafouz-Milne is of the opinion that the differences identified suggest that "there is some room for internal variation across languages in the construction of opinion columns" (110).

\section{Methodology}

The data for this study were ten opinion columns from five Nigerian daily newspapers: The Punch (texts 1 and 2), The Nation (texts 3 and 4), The Guardian (texts 5 and 6), Daily Trust (texts 7 and 8) and Sunday Sun (texts 9 and 10). Two columns written by each of the five columnists mentioned above in the introduction section were selected from each newspaper in January, 2018. The topics that were discussed by the columnists were farmer-herder conflict (ranching, cattle colony, restructuring, economy and governance) and family issues. The opinion columns selected were based on the aforementioned two areas, as Dafouz-Milne (2008) is of the opinion that there is the need to control the topic variable. When the topics are not controlled, the type, 
frequency of occurrence and distribution of metadiscourse markers used in the texts may be affected.

This study focused on the use of textual and interpersonal metadiscourse markers as classified by Dafouz-Milne (2008) in the data. All the macro categories and subcategories are employed for the analysis. The identification, categorisation and analysis of the metadiscoursal words and expressions were manually done. This is because many metadiscourse markers are multi-functional and thus, automatic searches for them through the use of software may not reflect their other functions. As such, one would still need to carry out the analysis manually to ensure its validity (Dafouz-Milne, 2008). The metadiscourse markers in each text were then investigated for their frequency of occurrence and results were presented in statistical forms.

Therefore, this study will help in identifying the metadiscourse markers that are used, and predominantly occur in Nigerian newspaper opinion columns.

\section{Data Analysis}

This section presents the analysis of the macro-categories and their sub-categories as metadiscourse markers in the data.

\section{Textual Metadiscourse Analysis}

Logical markers: These have the function of expressing semantic and structural relationships within discourse stretches. As a macrocategory, these markers have additive, adversative, consecutive and conclusive as sub-categories. The following are examples of logical markers in the data: and, either...or, furthermore, moreover, similarly, in addition, yet, but, however, or, so, besides, in sum, not only... but also, my take, therefore, etc. They are used in the following examples:

1. Text 2: Similarly (additive), cattle are the mainstay of the economy of Uruguay in South America, where cows outnumbered people by 4 to 1. Yet (adversative), cows do not destroy crops or block traffic on the roadways, because every cow farmer in the country operates within a gated ranch.

2. Text 4: Cows are amoral; therefore (consecutive), other people's farms, crops, land, etc. are supposed to be off limits to other people's cows.

3. Text 7: My take (conclusive) is that if you give them the chance, they would do more than play politics. 
It is noticed that there are instances where "but" is not used together with "also" in the correlative conjunction "not only...but also". This is because the second conjunct's value, "but also" can also be "but" or "also" alone, as shown in the following examples:

It appears it is not only motorists that are stopping now; Nigeria is also stopping... for cows (Text 4).

And yet the same Sambisa forest has miraculously grown not only with new shrubs ..., it has also grown with new Shekau insurgents (Text 8).

Sequencers: This is a macro-category that has the function of marking a particular position in a series. Sequencers help the columnists to indicate the particular issue being discussed and to arrange issues sequentially. Examples of sequencers in the data are: there is first, first, second, on the one hand, on the other hand, to start with, the other, etc. They are used in the following examples:

4. Text 1: Second, Trump is either totally oblivious to, or gloats over, the history of slavery, which brought millions of Africans into the United States as involuntary minorities.

5. Text 3: There is first, the unfortunate Benue State Massacre; that is very sad indeed.

In example 5, the writer uses "there is first" to indicate the first topic to be discussed in the text, as the writer has stated in the preceding paragraph that there are so many topics to be discussed. As opposed to the use of "first", it seems "there is first" is more interactive. It engages the readers more than "first".

Reminders: The use of these metadiscourse markers helps a writer to make reference or refer to a previous section or statement in the text. In the ten columns analysed as the data, the columnists did not employ the use of reminders in their texts.

Topicalisers: These help the writer to indicate topic shifts within a text. In some cases, more than one topic can be discussed within a text or a text can have sub-topics. It is the use of topicalisers that will show that another topic or sub-topic is being discussed. They are used in the data in the following examples:

6. Text 6: On the restructuring issue, for instance, now the APC appear to have made a sharp volte-face against its perceived 
earlier obdurate stand by reeling out what sounded like what Nigerians want.

7. Text 8: Corruption fight, as has become evident, has been lurching forward and backwards, making only steady gains here and there while corruption itself seems to be waxing stronger.

Topicalisers are usually sparsely used in opinion columns. This is because columnists normally have one topic and, occasionally, few subtopics to discuss. In text 6 , the columnist discusses restructuring and the planned establishment of cattle colonies as two contending issues confronting the government of All Progressive Congress (APC) in Nigeria. In example 6, "on the restructuring issues" is used to indicate that the discussion has shifted from cattle colonies to restructuring. Also in example 7, "corruption fight" is used by the columnist to indicate topic shift from insecurity that is discussed in the preceding paragraph.

Code Glosses: As a macro-category, code glosses help writers to explain, exemplify, rephrase or expand the point raised in their texts. Within this macro-category, there are parentheses, punctuation devices, reformulators and exemplifiers as sub-categories. Their uses in the data are exemplified below:

8. Text 3: Since my English is not very good (not being a native speaker and all), I could only understand that the president said something to the effect that there was no call to go restructuring the country (parenthesis).

9. Text 5: Ignoring ranching, (punctuation device) which is the globally accepted modern method of cattle farming and instead presenting cattle colony suggests something is fishy.

10. Text 8: Whichever way the re-ordering of the sequence of elections goes, the 2019 polls, give and take, will not go beyond April next year; meaning that (reformulator) effectively, Nigerians have just one year to return to the polls to elect and re-elect their leaders.

11. Text 5: Whereas, a ranch is an area of land with facilities and structures set up for raising grazing livestock such as (exemplifier) cattle, for meat or wool, cattle colony is totally different both in terms of purpose and structure. 
It is noticed that Dafouz-Milne's (2008) taxonomy does not encapsulate the use of pull quote. A pull quote, also known as a lift-out, is a quotation or excerpt that has been "pulled" from an article to entice readers or to highlight a key topic. Sometimes, pull quotes are italicised. In columns, pull quote can be placed under the topic or inserted within two columns of a text. As a pull quote is used to emphasise textual materials, it should be a subcategory under code glosses.

Illocutionary Markers: These explicitly name the act the writer performs. Examples of illocutionary markers in the data are: I pray, I must confess, I wish, I'd focus on, etc. They are used in the following examples:

12. Text 3: After looking at mine, I would want to wish you and myself more hard work, greater achievements, funnier PU, and better luck this year.

13. Text 9: The jobless wife, the wife without an income is the one I'd rather focus on.

As the examples have shown, illocutionary markers are always preceded by the first person singular pronoun "I" as the writer usually names the act he or she is performing.

Announcements: These have the function of helping writers of opinion texts to refer forward to future sections in the text. In the data analysed, the columnists did not employ the use of announcements as metadiscourse makers.

\section{Interpersonal Metadiscourse Analysis}

Hedges: The use of hedges as metadiscourse markers helps writers not to be totally committed to the truth-value of their texts. In other words, they help writers to be cautious in making remarks. Hedges have three sub-categories: epistemic verbs, probability adverbs and epistemic expressions. The following are the hedges in the data: may, may be (epistemic verbs); perhaps, nearly, hardly, maybe (probability adverbs) and the president seemed, I have heard, I doubt, it appears (epistemic expressions). They are used in the data in the following examples:

14. Text 7: For now, President Buhari may (epistemic verb) not have had the Nigerian equivalent of President Donald Trump's fire and fury to contend with... 
15. Text 6: Perhaps (probability adverb), one way out is for the APC-led Federal Government to back down on its proposed cattle colony and instead allow states to take charge ofland resources as appropriate.

16. Text 4: I have also heard it said (epistemic expression) that the Fulani herdsmen are actually the 'cow carers' for other wealthy cow owners such as presidents, emirs, governors, politicians, etc. who are the real owners of the cows.

Certainty Markers: These are the opposite of hedges. They are used to express total commitment to the truth-value of the text. In other words, writers use certainty markers to tell readers that they are sure of their propositions which they consider irrefutable. Examples of certainty markers in the data are: strongly believe, so clear, certainly, definitely, it is very clear, there is no doubt, etc. They are used in the following examples:

17. Text 2: I strongly believe that the Minister of Agriculture can get us there.

18. Text 7: There is no doubt that the herdsmen phenomenon predated the Buhari regime.

Certainty markers are used by the columnists to present facts and opinions in assured expressions. The reason for this is that, "readers expected to find the writer's opinion overtly stated" (Dafouz-Milne, 2008:108).

Attributors: These metadiscourse markers are used to make reference to the source of information. While they perform the function of attributing a proposition to a particular source, they also help in validating propositions in the texts. The following are examples of attributors in the data: the Inspector General of Police, Ibrahim Idris, said so; the minister of agriculture, Audu Ogbeh confirmed it; the president said; like everyone has been saying; Nigerians are saying; reports indicate; etc. They are used in the examples below:

19. Text 2: Reflecting on the contrast in his experiences as a military dictator and a democratically elected president, Buhari confessed: "this is why I am not in a hurry virtually to do anything. I will sit and reflect and continue with my clear conscience." 
20. Text 10: Did you read Asiwaju's unhappy wife in a recent interview; "I was hurt by what they did to my husband after campaign. We were running three campaigns in my house and for him to be trashed like that..."

As references can be made to specific and known sources, they can also be made to non-specific sources. For example:

(i) Like everyone has been saying, the federal government's silence on the murderous activities of the herdsmen all over the country is indeed baffling...

(ii) Many have said it is because the president is himself a Fulani man and so he finds it difficult to call his own people to order.

When this happens, the claims cannot be pinpointed to a particular source and the columnist cannot be held responsible for the claims made as well.

Attitude Markers: These markers have deontic verbs, attitudinal adverbs, attitudinal adjectives and cognitive verbs as sub-categories. Their function is to express writer's affective values towards the contents of the text and the reader. Examples of attitude markers in the data are: have to, need to and must (deontic verbs); honestly, fortunately, unfortunately and woefully (attitudinal adverbs); surprising, baffling and bad (attitudinal adjectives) and believe, know, hope, think and wonder (cognitive verbs). They are used in the following examples:

21. Text 6: Whatever needs to (deontic verb) be done should be done urgently without delay.

22. Text 7: Unfortunately, (attitudinal adverbs) government left the two sides to their own respective devices.

23. Text 10: That 73 people were buried in one day and the President opted not to go to Makurdi but Nasarawa where the casualty figure was lower in humans than cows is bad, very bad (attitudinal adjective).

24. Text 1: I know (cognitive verb) that Buhari means well for this country and its people, regardless of region, ethnicity or religion.

Commentaries: These are used by writers to establish and maintain reader-writer rapport in their texts. In other words, they are 
used by writers to interact with their readers. There are five subcategories of commentaries: rhetorical questions, direct address to reader, inclusive expressions, personalisations and asides. They are used in the data in the following examples:

25. Text 5: Could the minister now see that the cattle colony is a place for slaughtering the animals and not for grazing? (rhetorical question).

26. Text 10: APC, if you (direct address to reader) ask me, is losing grip on reality.

27. Text 8: We have been told, and we (inclusive expression) celebrated prematurely, that Sambisa forest, the fortress of the Boko Haram insurgents, had been levelled down.

28. Text 3: There is nothing wrong with me going around with all of my thirty-two (sorry, I think it's remaining twenty-nine and a half or so now....) (aside)

In the data, the second person pronouns "you" and "your" are used to express direct address to reader. However, it is observed that there are instances of subject-less sentences being used to address reader. For examples: pray that the state care (text 3) and hold that thought (text 9). In the two examples, the readers are being addressed by the columnists without a definite addressee but "you" can be added as the subject. Thus, we can have, "you should pray that the state care" and "you should hold that thought".

For inclusive expressions, pronouns such as us, our and we are used. But there is an instance where "you and I" is used as an inclusive expression: "Already, there are so many topics asking you and I to knock heads together on this column". This expression is used by the columnist to engage readers in the topic(s) of discussion and to tell them that "they are together". Therefore, a kind of camaraderie feeling is built.

\section{Discussion}

The analysis of the data that constitute this study further corroborates the fact that metadiscourse markers are essential in the construction and attainment of persuasion in opinion columns. However, while the analysis reveals that both the textual and interpersonal metadiscourse markers were employed in the data, some were more favoured than others in their usages. As Dafouz-Milne (2008: 96) argues, "to succeed, writers need to create a credible textual persona 
or ethos and develop an appropriate attitude towards their readers and the claims they present". Therefore, propositional materials need to be presented by the columnists in a way their readers will find most convincing.

Concerning textual metadiscourse markers, out of 297 textual metadiscourse markers in the data, there are $213(71.7 \%)$ logical markers. Within this category, there are 127 (42.7\%) additives, 67 (22.55\%) adversatives, 16 (5.38\%) consecutives, and 3 (1.01\%) conclusives. The implication of this is that the use of additives is favoured in the analysed newspaper opinion columns to build arguments in order to achieve persuasive purposes. Through this, positive propositions are added to the topic sentence. Also, adversatives are equally used in constructing arguments to present both the merits and the demerits of an argument. This is the reconstruction of an argument based on the "pros and cons of an opinion" (Dafouz-Milne, 2008:106). Lastly, the negligible use of conclusives indicates that their use is not favoured at this level as opinion writers are expected to conclude their argument without necessarily stating the obvious.

The analysis of textual metadiscourse markers is shown in the table below:

\begin{tabular}{l|l|l} 
Macro-category & Subcategory & Number of markers \\
\hline Logical Markers & Additive & $127(42.76 \%)$ \\
& Adversative & $67(22.55 \%)$ \\
& Consecutive & $16(5.38 \%)$ \\
& Conclusive & $3(1.01 \%)$ \\
& (total) & $\mathbf{2 1 3 ( 7 1 . 7 \% )}$ \\
\hline Sequencers & & $\mathbf{1 4 ( 4 . 7 1 \% )}$ \\
\hline Reminders & & - \\
\hline Topicalisers & & $\mathbf{1 2 ( 4 . 0 4 \% )}$ \\
\hline Code glosses & Parentheses & $3(1.01 \%)$ \\
& Punctuation devices & $32(10.77 \%)$ \\
& Reformulators & $3(1.01 \%)$ \\
& Exemplifiers & $9(3.03 \%)$ \\
\hline Illocutionary Markers & (total) & $\mathbf{4 7 ( 1 5 . 8 2 \% )}$ \\
\hline Announcements & & $\mathbf{1 1 ( 3 . 7 \% )}$
\end{tabular}

Table 5: Frequency of occurence of textual metadiscourse categories and sub-categories

Code glosses had the highest number of markers after logical markers. Out of the four sub-categories of code glosses, punctuation devices had the highest frequency of occurrence in the data. This means that the columnists favour the use of punctuation devices such as commas, hyphens and colons to explain, rephrase and exemplify their 
arguments. The sparsely use of other subcategories might be due to the need to economise words as there are limited and restricted spaces for opinion columns.

The frequency of occurrence of sequencers, topicalisers and illocutionary markers is low. Regarding sequencers and topicalisers, the reason for this might not be unconnected with the fact that most of the analysed opinion columns do not have subtopics apart from the main topic introduced in the heading. The heading usually introduces the main topic and there is no need to overtly topicalise within the text. This relatively affects the use of sequencers as the columnists prefer the use of additives and adversatives to add to and balance arguments. Regarding the use of illocutionary markers, it is found that the acts being performed by the columnists are not usually stated. The reason for this is that the acts are inherent in the texts and readers can easily see and understand them.

Lastly, reminders and announcements were not used in the data. What this suggests is that they are not favoured to be used in opinion columns. As Dafouz-Milne (2008: 107) states, the interpretation is that their "prospective and retrospective functions... are not necessary in such a short-length genre".

Within the interpersonal metadiscourse markers, as shown in table 6 below, the most frequent markers were commentaries.

\begin{tabular}{l|l|l} 
Macro-category & Sub-category & Number of Markers \\
\hline Hedges & Epistemic Verbs & $10(2.3 \%)$ \\
& Probability Adverbs & $5(1.1 \%)$ \\
& Epistemic Expressions & $21(4.7 \%)$ \\
& (total) & $\mathbf{3 6}(\mathbf{8 . 1 \% )}$ \\
\hline Certainty Markers & & $\mathbf{1 6}(\mathbf{3 . 6 \% )}$ \\
\hline Attributors & & $\mathbf{3 1 ( 7 \% )}$ \\
\hline Attitudes Markers & & $\mathbf{5 0 ( 1 1 . 3 \% )}$ \\
& Deontic Verbs & $5(1.1 \%)$ \\
& Attitudinal Adverbs & $11(2.5 \%)$ \\
& Attitudinal Adjectives & $9(2 \%)$ \\
& Cognitive Verbs & $25(5.6 \%)$ \\
\hline Commentaries & Rhetorical Questions & $66(14.9 \%)$ \\
& Direct Address to Reader & $44(9.9 \%)$ \\
& Inclusive Expressions & $68(15.3 \%)$ \\
& Personalisations & $130(29.3 \%)$ \\
& Asides & $3(0.7 \%)$ \\
& (total) & $\mathbf{3 1 1}(\mathbf{7 0 \% )}$ \\
\multicolumn{2}{c}{ Table 6: Frequency of occurrence of } \\
\multicolumn{2}{c}{ interpersonal metadiscourse categories and sub-categories }
\end{tabular}


They were used 311 times (70\%) out of the entire 444 interpersonal markers in the data. The implication of this is that the columnists are highly committed to the establishment of a writer-reader relationship in their texts. Within its four subcategories, personalisations and inclusive expressions have the highest frequency of occurrence. Although the high presence of personalisations in a text can portray the writer as being subjective (Noorian and Biria, 2010), readers still expect the presence of columnists in their texts and this helps in the building of interaction. The profuse use of inclusive expressions helps in establishing solidarity between the columnists and their readers. Through this, the columnists are telling the readers, usually the "ordinary" citizens of the country, that they are fighting for their cause. In other words, they are telling them that "what concerns you also concerns us" and "we are together in this situation".

Also the high frequency of occurrence of rhetorical question and direct address to readers shows their importance in achieving persuasion. Both strategies are used to manipulate the readers to follow the writer's line of arguments. Rhetorical questions are used to spell out questions meant for the readers to answer and direct address to reader is used to call out readers in an argument. The implication of this is that both strategies are used to sway the reader's belief opinion and conviction to be in line with that of the columnist.

Lastly when it comes to commentaries, asides have the least frequency of occurrence. This means that they are not favoured in the analysed newspaper opinion columns. While English and Spanish columnists encourage the use of asides (Dafouz-Milne, 2008), they are not by Indonesian columnists (Sukma and Sujatna, 2014). A possible explanation for this may be linked to cultural differences among language communities which a contrastive study may be able to account for.

Attitude markers also have a high frequency of occurrence in the data. This supports the findings of Dafouz-Milne (2008) that the expression of feelings by opinion columnists is an important persuasive tool. Opinion column writers need to make their personal feelings known in their texts as the readers want to know their feelings towards the topics of discussion.

Hedges have the third highest frequency of occurrence. Columnists should not throw caution to the winds in presenting their arguments. It is unsurprising that attributors and certainty markers appear next in the frequency of occurrence. The claims of columnists need to be well attributed. As such the statements cannot be linked to the columnists. This is another covert way of hedging that helps opinion writers not to commit themselves to some statements in their texts. Also, 
the use of attributors and certainty markers also help in persuading readers. A columnist will earn the trust of his or her reader when the claims in his text are referenced and the columnist also shows total commitment to his or her claims through the use of certainty markers. Therefore, it is crucial in persuasive texts for writers to strike a balance in the use of hedges, attributors and certainty markers.

\section{Conclusion}

This paper has focused on the presence and use of metadiscourse markers in opinion texts written by Nigerian columnists. The study reveals that the columnists employ both the textual and interpersonal metadiscourse markers in their texts. Only reminders and announcements, two categories under textual metadiscourse markers are not employed in the data. However, the metadiscourse taxonomy employed in this study should be modified for further studies. Pull quote should be added as a sub-category of code glosses under textual metadiscourse while specific sources and non-specific sources should be included as sub-categories of attributors under interpersonal metadiscourse.

The implication of the employment of metadiscourse markers by the columnists is summarised by Hyland \& Tse (2004), who conclude that "writing effectively means anticipating the needs of readers, both to follow an exposition and to participate in a dialogue and occasionally, devices are used to perform both functions at once" (p.157). Therefore, the columnists can be said to write effectively as their employment of metadiscourse markers shows that they are conscious of their readers' needs.

Concerning the differences, it is found out that there is a significant difference in the use of textual and interpersonal metadiscourse markers. The total number of interpersonal markers is 444 (59.92\%), while that of textual markers is $297(40.08 \%)$, of the total 741 metadiscourse markers employed by the columnists. This possibly implies that the columnists value their interaction and relationship building with their readers.

Lastly, there are limitations to this study. First of all, the study is not a contrastive analysis. The use of metadiscourse markers can be contrasted in different genres and subgenres such as columns, editorials and news items. Its use can also be explored cross-culturally in order to discover possible cultural differences. Another limitation is in the area of extra-textual considerations. The level of education, years of experience as writers and the gender of the columnists are not considered in the analysis. All these can play a significant role in the use of metadiscourse markers by columnists. Therefore, cross-cultural 
studies and studies that focus on extra-textual factors can be a valuable extension to this investigation.

\section{References}

Akinnaso, Niyi. "A Tale of Two Presidents: Trump and Buhari." The Punch, 16 Jan. 2018: 40.

--------. "Ranching is the Best Solution. The Punch, 23 Jan. 2018: 40.

Amiryousef, Muhammad and Rasekh, Abbass E. "Metadiscourse: Definitions, Issues and Its Implications for English Teachers." English Language Teaching, 3, 4, 2010: 159-67.

Bednarek, Monika and Caple Helen. "News Discourse." London: Continuum, 2012.

Crismore, Avon, Markkanen Raija and Steffensen Margaret. "Metadiscourse in Persuasive Writing: A Study of Texts Written by American and Finnish University Students." Written Communication, 10, 1, 1993: 39-71.

Dafouz, Emma. "Metadiscourse Revisited: A Contrastive Study of Persuasive Writing in Professional Discourse". Estudios Ingleses de la Universidad Complutense 11, 2003: 29-52.

Dafouz-Milne, Emma. "The Pragmatic Role of Textual and Interpersonal Metadiscourse Markers in the Construction and Attainment of Persuasion: A Cross-linguistic Study of Newspaper Discourse." Journal of Pragmatics, 40, 1, 2008: 95-113.

Egbemode, Funke. "Rich Wife, Poor Wife." Sunday Sun, 21 Jan. 2018: 60.

-----.. "Shall We Tell the President?” Sunday Sun, 25 Feb. 2018: 60.

Farrokhi, Farahman, and Emami Safoora. "Hedges and Boosters in Academic Writing: Native vs. Non-native Research Articles in Applied Linguistics and Engineering." The Journal of Applied Linguistics, vol. 1, no 2, 2008: 62-96.

Halliday, Michael, A. K. An Introduction to Functional Grammar." London: Arnold, 1994.

Hyland, Ken. "Persuasion and Context: The Pragmatics of Academic Discourse." Journal of Pragmatics, 30, 1998: 437-55.

.Metadiscourse: Exploring Interaction in Writing." Oxford: Continuum, 2005.

Hyland, Ken. and Tse Polly. "Metadiscourse in Academic Writing: A Reappraisal." Applied Linguistics, 25 2, 2004: 156-77.

Latawiec, Beata M. "Metadiscourse in Oral Discussions and Persuasive Essays of Children Exposed to Collaborative Reasoning." A Doctoral Dissertation, the University of Illinois at Urbana-Champaign, 2012.

Le, Elizabeth. "Active Participation within Written Argumentation: Metadiscourse Editorial's Authority." Journal of Pragmatics, 36, 2004: 687-714.

Marandi, Susan. "Metadiscourse in Persian and English Master's Thesis: A Contrastive Study." Iranian Journal of Applied Linguistics, 6, 2, 2003: 2342.

Medubi, Oyinkan. "My New Year's Wish for You.” The Nation, 14 Jan. 2018: 20. ."Why is Nigeria Stopping...for Cows?" The Nation, 21 Jan. 2018: 20. 
Mohammed, Yusuf. "This is not President Buhari's Fire and Fury." Daily Trust, 10 Jan. 2018: 50.

"Buhari: A Case for Empathy and Positive Symbolism." Daily Trust, 21 Feb. 2018: 50.

Noorian, Mina and Biria Reza. "Interpersonal Metadiscourse in Persuasive Journalism: A Study of Texts by American and Iranian EFL Columnists." Journal of Modern Languages, 20, 2010: 64-79.

Ojo, Oluwasola E. "A Contrastive Rhetoric Analysis of Presidents Barack Obama and Goodluck Jonathan's Inauguration Speeches." Unpublished M.A. Thesis, Department of English, University of Ilorin, Ilorin, 2013.

Onyekakeyah, Luke. "What is Cattle Colony?" The Guardian, 16 Jan. 2018: 17.

-------. “APC, Restructuring and Cattle Colonies.” The Guardian, 30 Jan. 2018. 17.

Sukma, Bayu, P. and Sujatna, Eva T. (2014). "Interpersonal Metadiscourse Markers in Opinion Articles: A Study of Texts Written by Indonesian Writers." International Journal of Applied Linguistics and English Literature, 3, 2, 2014: 16-21.

Thompson, George. "Interaction in Academic Writing: Learning to Argue with the Reader." Applied Linguistics, 22, 1, 2001: 58-78.

Van Dijk, Teun. "News as Discourse." Hillsdale, NJ: Lawrence Erlbaum, 1988.

Vande Kopple, William. "Some Exploratory Discourse on Metadiscourse." College Composition and Communication, 36, 1985: 82-93.

Vande Kopple, William. "Refining and Applying Views of Metadiscourse." Paper Presented at the Annual Meeting of the Conference on Composition and Communication (48th), AZ, Phoenix, 1997.

Zarei, Gholam, R. and Mansoori Sara. "Metadiscourse in Academic Prose: A Contrastive Analysis of English and Persian Research Articles. The Asian ESP Journal, 3, 2, 2007: 24-40. 